\title{
A Quarzal ${ }^{\circledR}$ termékek jellemzói és viselkedése, avagy korszerú-e még a slikkeröntéssel gyártott szilika az üvegiparban? ${ }^{1}$
}

\begin{abstract}
DiPL.-ING. GüNTER FiEDERLING - Kutatás és Fejlesztés, SCHOTT AG
Érkezett: 2009. 10. 18. - Received: 18. 10. 2009.

Characteristics and behavior of the slip-cast material Quarzal ${ }^{\circledR}$ or is slip-cast fused silica still up-to-date for glass production?

The slip-cast fused silica material Quarzal ${ }^{\circledR}$ has been produced and used by SCHOTT for more than 30 years. Since 3 years Quarzal ${ }^{\circledR}$ is marketed outside SCHOTT. Quarzal ${ }^{\circledR}$ has a low glass defect potential both for solid defects and bubbles, as well as outstanding thermal shock resistance. It also shows excellent resistance to low-alkali glasses. The good solubility of Quarzal ${ }^{\circledR}$, which is nearly $100 \% \mathrm{SiO}_{2}$ does not occur any striaes in the glass products. The applied slip casting process allows the production of moldings like: feeder expendables (spout, tubes, plunger and orifice rings), tweel, flat arches, channel blocks, stirrers, burner blocks and of large components, which enable efficient furnace or forehearth designs.
\end{abstract}

\section{Bevezetés}

A mai üvegolvasztó kemencék üveggel érintkező anyagai leggyakrabban az olvasztva öntött termékek (AZS, HZFC), valamint az izosztatikusan préselt cirkonszilikátok. E tüzálló kövek jól ismert előnye az üvegkorrózióval szembeni nagyfokú ellenállóképességük, amely a magas tömegsürüségnek, az ebböl eredő alacsony nyitott porozitásnak valamint az alkotó komponenesek alacsony oldódásának köszönhető.

Sokkal kevésbé használatosak az üveggel érintkező anyagok közül a slikkeröntéssel gyártott szilikák, melyek a nyitott porozitást valamint az üvegben való oldékonyságukat tekintve az előbbiektől határozottan különböznek. Gyártástechnológiai okokból a slikkeröntéssel gyártott sziliák nyitott porozitása $15 \%$ körül van és a közönséges üvegben történő oldódásuk is magasabb.

A SCHOTT AG kemencetervezési részlegének egyik legfontosabb anyaga a slikkeröntéssel gyártott szilika. A cég ezt a terméket Quarzal ${ }^{\circledR}$ márkanéven már több mint 25 éve gyártja belső használatra.

A folyamatosan változó üvegösszetétel, a különféle olvasztókemencék nagy száma, valamint az üvegminőség javításának állandó igénye mind a Quarzal ${ }^{\circledR}$ fejlesztését ösztönző tényezők. Mind a termék tulajdonsága, mind pedig a késztermék megformázása és megmunkálása a folyamatos tökéletesítés tárgya. A következőkben egy rövid leírást adunk a gyártási folyamatról, áttekintést az anyag jellemzőiről és viselkedéséről, majd gyakorlati példákon bemutatjuk, hogy miért a Quarzal $^{\circledR}$ az egyik legfontosabb és legkorszerübb SCHOTT termék. Ezek a példák segítenek illusztrálni ennek a rendkívüli anyagnak a széleskörü alkalmazhatóságát is.

\section{A Quarzal ${ }^{\circledR}$ elöllítása}

A Quarzal ${ }^{\oplus}$-t a hagyományos slikkeröntéses eljárással alakítják ki. A nyersanyag kizárólag öntött szilika, vagyis a szuszpenzió 100\%-ban adalékanyag nélküli. Ez a reológiai tulaj-

\footnotetext{
A 2009. április 28-án, Budapesten megrendezett Üvegipari Szakmai Konferencián
} elhangzott elöadás alapján. donságok kézben tartása mellett azért is fontos, mert ezeknek az adalékoknak a buborékosodást okozó maradék széntartalmát ezzel ki lehet küszöbölni.

A nyersanyagok kiválasztásán kívül az előkészítési technika is fontos szerepet játszik a Quarzal elóállításában. Az extrém kemény öntött szilika nyersanyag durva aprítása során a törőpofák komoly kopásnak vannak kitéve. A koptatásból keletkező fémmaradványok hatékony eltávolítása szeparátorokkal történik. $A$ vas és más fémszennyeződések szintjének alacsonyan tartása érdekében a SCHOTT cég egy speciális leválasztó rendszert fejlesztett ki. Golyós és vibrációs malmok biztosítják az öntött szilika finomőrlését. Az őrlőtest $\mathrm{Al}_{2} \mathrm{O}_{3}$-t tartalmaz, amely ebből következően a fö szennyező a késztermékben. Tökéletesített örlési technikával minimalizálni lehet az $\mathrm{Al}_{2} \mathrm{O}_{3}$ tartalmat. Nagyon finom őrlési folyamatok alkalmazásával a szuszpenzió nedvességtartalmát nagyon alacsonyan, $\mathrm{kb} .15$ súly\%-on lehet tartani. Ezáltal a száradási és égetési zsugorodás kevesebb, mint 2\%, így nagyobb blokkok is könnyen legyárthatók. A gyártható méretet nem is annyira a formázási folyamat, mint inkább a kemence méretei és a kezelési problémák korlátozzák (max. súly kb. $3 \mathrm{t}$ ). A tipikus SCHOTT méretek: $2,5 \mathrm{~m} \times 2,0 \mathrm{~m} \times 0,3 \mathrm{~m}$ vagy $2,0 \mathrm{~m} \times 1,9 \mathrm{~m} \times 0,32 \mathrm{~m}$. A slikkeröntés a méretes blokkok gyártásán kívül természetesen lehetővé teszi egyedi megrendelésre és speciális alkalmazásra szánt termékek elkészítését is.

\begin{tabular}{lc} 
Szennyezők & ppm \\
$\mathrm{Al}_{2} \mathrm{O}_{3}$ & $360{ }^{*}$ \\
\hline $\mathrm{CaO}$ & 66 \\
\hline $\mathrm{CoO}$ & $<20$ \\
\hline $\mathrm{Cr}_{2} \mathrm{O}_{3}$ & $<20$ \\
\hline $\mathrm{Na}_{2} \mathrm{O}$ & $<10$ \\
\hline $\mathrm{MgO}$ & 79 \\
\hline $\mathrm{Fe}_{2} \mathrm{O}_{3}$ & 19 \\
\hline $\mathrm{TiO}_{2}$ & $<20$ \\
\hline${ }^{*} \mathrm{Speciális} \mathrm{esetben} \mathrm{alacsonyabb} \mathrm{Al}_{2} \mathrm{O}_{3}$ is lehetséges \\
\hline${ }^{1 .}$ táblázat & A Quarzal föbb szennyezöi \\
Table 1. Main contaminants of Quarzal &
\end{tabular}




\section{A Quarzal ${ }^{\circledast}$ jellemzői}

A Quarzal ${ }^{\oplus}$ tulajdonságait elsősorban a szuszpenzió szemcseméret-megoszlása, előkészítése, valamint az égetés hőmérséklete (kb. $1100{ }^{\circ} \mathrm{C}$ ) határozza meg. Magasabb égetési hőmérséklet kristályosodást okoz (az öntött szilika krisztobalittá alakul), ami az alkotóelemek tönkretételét okozhatja (lásd alább is). Az 1. táblázat mutatja, hogy a Quarzal ${ }^{\circledR}$ fö szennyezője az alumínium, ugyanakkor a vas és a titán, melyek a több vegyértéküségük miatt befolyással vannak a hólyagképződésre, csak kis mennyiségben vannak jelen. Az összességében nagyon csekély szennyezőkkel a Quarzal ${ }^{\oplus}$-t a krisztobalit olvadáspontjához $\left(1723^{\circ} \mathrm{C}\right)$ közeli hőmérsékleten is lehet alkalmazni. A 2. táblázat a két jelentősebb Quarzal ${ }^{\circledR}$ minőség jellemző tulajdonságait mutatja. A terméknek ezenkívűl nagyon jó a hőlökésállósága, amely az alacsony hőtágulási együttható (az öntött szilikáéhoz hasonlóan: $0,5 \times 10^{-6} 1 / \mathrm{K}$ ) eredménye. A Quarzal ${ }^{\oplus}$ legfőbb sajátossága, hogy nagyon kis mértékben hajlamos üveghibák okozására. Az a hátránya, miszerint elég jól oldódik üvegolvadékokban, egyben elönyére is válik, mivel a szilika negatív hatások nélkül oldódik a szilikát-üvegolvadékokban. Összevetve a $\mathrm{ZrO}_{2}$-tartalmú, üveggel érintkező tüzálló anyagokkal, a vizuális üveghibák (pl. kövek) előfordulási esélye sokkal kisebb. AZS-anyagok alkalmazása során egy $\mathrm{ZrO}_{2}$-ban feldúsult reakció-fázis alakul ki, melyről részecskék (pl. hőmérséklet változtatás esetén elsősorban huzal) hajlamosak leválni. A Quarzal ${ }^{\circledR}$ elönyösen kombinálható platina ötvözetekkel is, és nagyon jól bevált hordozóanyagként nemesfém alkatrészekhez az üvegipar számára. Ezek az alkatrészek azon kívül, hogy jó mechanikai ellenállóképességgel rendelkeznek, vészhelyzetben is kiválóan müködnek, azaz nem kell őket azonnal kicserélni.

\begin{tabular}{lrr} 
& N típus & G típus \\
Tömegsūrúség $\left(\mathrm{g} / \mathrm{cm}^{3}\right)$ & 1,9 & 2,0 \\
\hline Látszólagos porozitás (térf. \%) & 13,0 & 10,0 \\
\hline Max. szemnagyság $(\mathrm{mm})$ & 1,0 & 6,0 \\
\hline Hajlító szilárdság (hideg) & 12,0 & 14,0 \\
\hline $\begin{array}{l}\text { Hajlító szilárdság }(\mathrm{meleg})\left(900^{\circ} \mathrm{C}\right) \\
24 \text { óra után } 1450{ }^{\circ} \mathrm{C}-\mathrm{on}\end{array}$ & 22 & 19 \\
\hline Égetési zsugorodás T $>1250^{\circ} \mathrm{C}(\%)$ & $<4,5$ & $<3,0$ \\
\hline Jellemzố termékek & $\begin{array}{r}\text { Vékony falú } \\
\text { alkatrészek }\end{array}$ & $\begin{array}{r}\text { Nagy méretú } \\
\text { blokkok }\end{array}$ \\
\hline Alkalmazások & $\begin{array}{r}\text { Tégelyek } \\
\text { Felépítmény }\end{array}$ & $\begin{array}{r}\text { Üveggel érint- } \\
\text { kezô elemek }\end{array}$ \\
\hline
\end{tabular}

2. táblázat Quarzal minőségek

Table 2. Quarzal ${ }^{\circledR}$ qualities

\section{A Quarzal ${ }^{\oplus}$ viselkedése}

A Quarzal ${ }^{\oplus}$-ból készült alkatrészek viselkedése nagyban függ az üzemi hőmérséklettől. $1150^{\circ} \mathrm{C}$-nál alacsonyabb hőmérsékleten a Quarzal ${ }^{\circledR}$ megmarad az eredeti - azaz öntött szilika - állapotában. Következésképpen megmarad az öntött szilikára jellemző alacsony hőtágulási együttható és hasonlóképpen a kiváló hőlökés-állóság. $1150{ }^{\circ} \mathrm{C}$-nál magasabb hőmérséklet és hosszú tartózkodási idő kristályosodást okoz, azaz az öntött szilika nagy hőmérsékleten stabil krisztobalittá alakul. A térfogatváltozás elhanyagolható (3. táblázat). Azonban a kristályosodásnak megvan az a hátránya, hogy a krisztobalit polimorf transzformációt szenved. Üzemi hőmérsékletről szobahőmérsékletre történő hütés közben, kb. $260^{\circ} \mathrm{C}$-nál, a nagy hőmérsékleten stabil krisztobalit alacsony hőmérsékleten stabillá alakul, ami egy 2-2,8\%-os térfogatcsökkenéssel is együtt jár. Ez a térfogatváltozás feszültséget okoz, amely könnyen tönkreteszi a Quarzal ${ }^{\circledR}$ alkatrészt. Ez azt jelenti, hogy azokat a Quarzal ${ }^{\oplus}$ alkatrészeket, melyek egy bizonyos ideig $1150{ }^{\circ} \mathrm{C}$-on müködnek nem lehet lehütés után újra felhasználni.

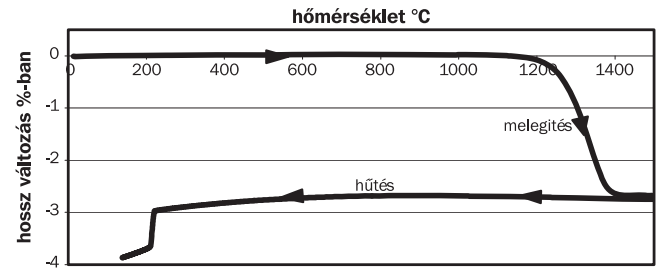

3. táblázat A Quarzal jellemző zsugorodási viselkedése

Table 3. Characteristic shrinking behavior of Quarzal ${ }^{\circ}$

\section{Felhasználási területek}

\section{1. Üveggel érintkező blokkok}

Az üveggel érintkező anyagok kiválasztásának legfontosabb szempontjai a meghatározott körülményeknek megfelelő tartósság, az üveghibák okozására való hajlam kérdése, valamint a költségek. A Quarzal ${ }^{\oplus}$ jó alternatívának bizonyul alacsony alkáliatartalmú (<5\%) üvegek esetén. Ilyen üvegeknél a Quarzal ${ }^{\circledR}$ olvasztókádak élettartama jó néhány év. A Quarzal ${ }^{\circledR}$ kádak alkalmasak a gyakori keverékváltoztatásokra is. Ilyenkor jelentkezik előnyként a kiváló hőlökés-állóság - függetlenül attól, hogy kialakult a krisztobalit vagy sem - valamint a blokkok felületéről hiányzó - vizuális hibákat okozó - reakció-fázis. Így az üvegösszetételt üveghibák megjelenése nélkül, nagyon gyorsan lehet változtatni.

A teljesen Quarzal ${ }^{\oplus}$-ból épített kádaknál a zsugorodás az első pillanatban problémának tűnhet. Valóban, a kötések a meleg zónában megnyílnak, de ahogy azt a 1 . ábra is mutatja, ezek nem okoznak szükségszerüen problémát.

Quarzal ${ }^{\circledR}$-ból csatorna blokkok is készülhetnek a feederekben, különösen boroszilikát üvegek részére.

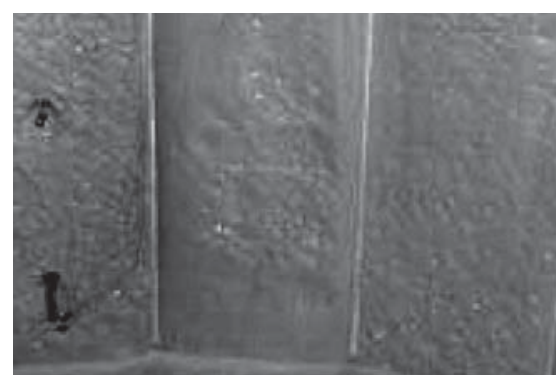

1. ábra Kemence 5 éves kampány után

Fig. 1. Kiln after a 5-year campaign

\section{Keverők}

A slikkeröntéses technológia lehetővé teszi az egyszerü ill. bonyolultabb Quarzal ${ }^{\circledR}$ formák elkészítését, mi több, megfelelö mechanikai utómunkálatokkal keverőket és plungereket lehet könnyen gyártani (2. ábra). Ezeknek az alkatrészeknek nagy elönye a slikkeröntött szilika anyagok által biztosított kiváló hőlökésállóságuk. A keverők néhány óra alatt kicserélhetők. Az ellenállóképességet illetően pedig hosszú élettartam várható alacsony alkáli üvegekben, míg a magas alkália és az ólom erősen korrodálják ezeket az anyagokat. 


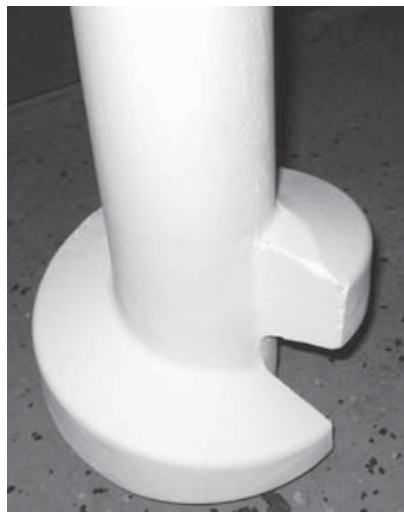

2a.ábra Kis keverö

Fig. 2a. Small mixer

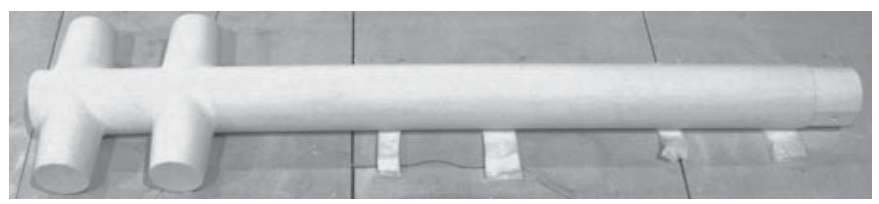

2b. ábra $2 m$ hosszú keverö, keverési átmérö $400 \mathrm{~mm}$

Fig. $2 b .2 \mathrm{~m}$ long, $400 \mathrm{~mm}$ diameter mixer

\section{Boroszilikát üvegeknél alkalmazott cseppgyürük (száj- darabok)}

Az alacsony alkáli tartalmú üvegek tipikus példája a Duran ${ }^{\circledR}$ üveg. Korábban az öblösüveg gyártásához használt Duran ${ }^{\circledR}$ üvegeknél nemesfémből gyártott cseppgyürüket alkalmaztak. Manapság csaknem az összes cseppgyürü Quarzal ${ }^{\circledR}$-ból készül. A Quarzal ${ }^{\circledR}$ gyürűk bevezetésének gátja volt a kezdetben fellépő hólyagosodási probléma. A bizonyos időközönként előforduló hólyagosodás oka az üveggel érintkező felület nyitott porozitása, viszont a hólyagosodást speciális anyagszerkezettel minimalizálni lehetett. A 3b. ábra egy szájdarabot mutat használat után. Látható, hogy a kb. $1250{ }^{\circ} \mathrm{C}$-on alkalmazott alkatrész kopása elhanyagolható, ami több hónapnyi müködést tesz lehetővé.

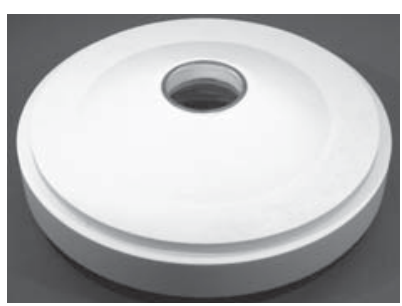

3a. ábra Quarzal speciális cseppgyürú Fig. 3a. Special Quarzal ${ }^{\varpi}$ drop-ring

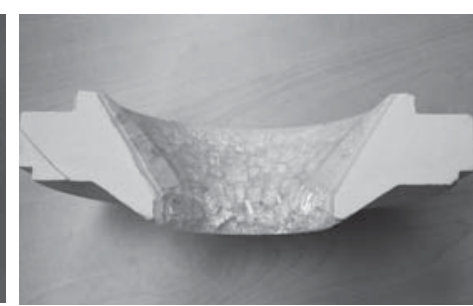

3b. ábra Quarzal ${ }^{\circledR}$ cseppgyürü 12 heti használat után

Fig. 3b. Quarzal ${ }^{\circledR}$ drop-ring after 12 weeks of use

\section{Fogyóeszközök}

Ahogy korábban is említettük a Quarzal ${ }^{\oplus}$-t kiváló hölökésállósága, valamint a nagyon kismértékű üveghiba okozó hajlama alkalmassá teszi arra, hogy az üvegformázási folyamatokban fogyóeszközként szerepeljen. A floatüveg gyártásban a tüzálló gátakhoz (4. ábra) kizárólag öntött szilikát használnak, de áthidaló elemek (5. ábra) is készülhetnek Quarzal-ból.

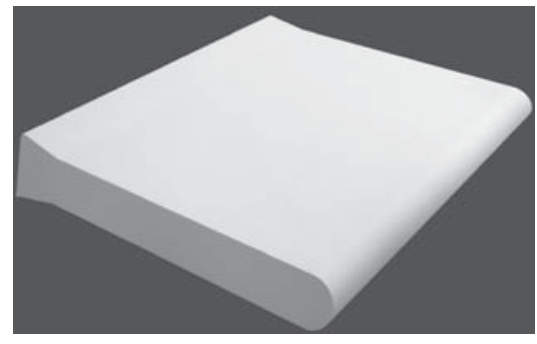

4. ábra Tüzálló gát ( tweel) Fig. 4. Refractory barrier

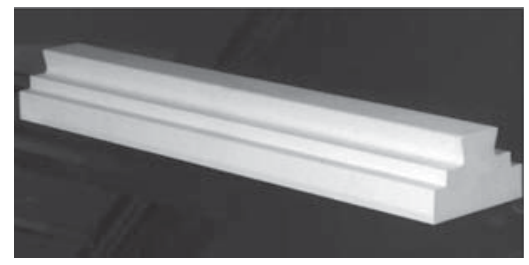

5. ábra Áthidaló elem

Fig. 5. Bridging element
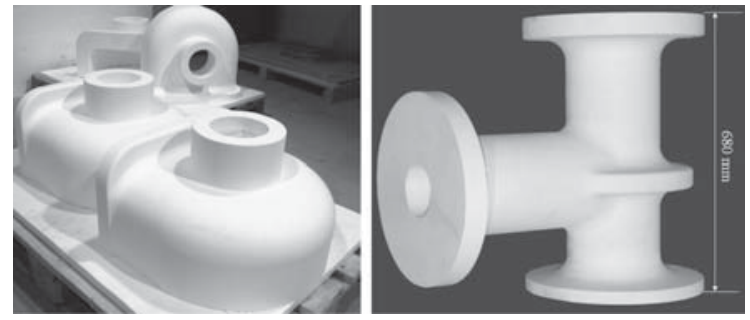

6. ábra Különféle csészék

Fig. 6. Various dishes

A boroszilikát öblösüveg gyártásban elöszeretettel használják a Quarzal ${ }^{\circ}$-t mint csészét (6. ábra), plungert (7. ábra) vagy égőkövet ill. csészefedő követ. A Quarzal ${ }^{\circ}$ a jó hőlökésállósága miatt üvegolvasztó fazekaskemencék anyagaként is használható, mivel ezeknek a felfütése nem úgy történik, mint az agyag esetében: itt nem szükséges a fazekat speciális felfütő kemencében feltemperálni.

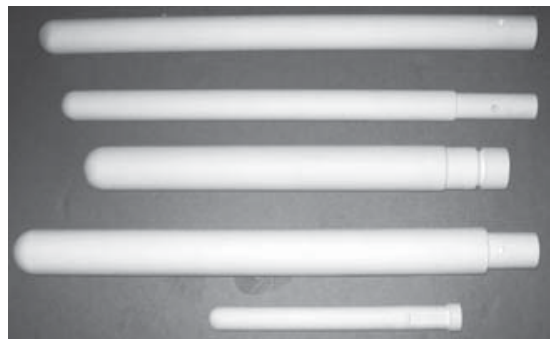

7. ábra Különbözö méretű plungerek

Fig. 7. Plungers of different size

\section{Egyéb alkalmazási lehetöségek}

$\mathrm{Az}$ üveggel közvetlenül érintkező anyagként történő felhasználásán kívül a slikkeröntött anyagokat többféle célra, pl. a síküveg gyártásban hűtőhengerként is fel lehet használni. A kiváló hőlökésállósága miatt a Quarzal -t égetési segédanyagokként - pl. síküveg hajlításánál vagy profil kialakításánál - is alkalmazzák. A nagy tisztasága miatt pedig speciális hőkezelések során (kalcinálás) vagy laboratóriumban burkolatokat és tégelyeket készítenek gyakran Quarzal ${ }^{\circledR}$-ból. 